\title{
ANTIOXIDANT ENZYMES AS DEFENSE MECHANISM AGAINST OXIDATIVE STRESS IN MIDGUT TISSUE AND HEMOCYTES OF Bombyx mori LARVAE SUBJECTED TO VARIOUS STRESSORS
}

\section{Ann Sandhya Micheal and Muthangi Veera Venkata Subramanyam \\ Department of Life Science, Bangalore University, Bangalore, India}

In this study, larvae of silkworm Bombyx mori were subjected to low temperature, hypoxia, and viral infection to evaluate stressor-mediated oxidative stress (OS) and the induction of antioxidant enzymes (AOEs). Exposure to cold, hypoxia, and nuclear polyhedral virus for $24 \mathrm{~h}$ resulted in a significant increase in hydrogen peroxide generation with concomitant increase in lipid peroxidation (LPO) and protein carbonyl levels in midgut and hemocytes. AOEs such as superoxide dismutase and catalase also increased significantly in both the tissues and the increased AOEs reverted to control values during recovery. Ontogenic stages of the larvae showed a diminishing ability of the tissues to overcome OS induced by the stressors. A significant increase in AOE activity during short stress period indicated a possible transitory defense mechanism to avoid OS-induced cell damage.

(C) 2013 Wiley Periodicals, Inc.

Keywords: oxidative stress; free radicals; antioxidant enzymes; lipid peroxidation; protein carbonyl 


\section{INTRODUCTION}

Reactive oxygen species (ROS), a by-product of oxidative metabolism in aerobic cells, are produced following the exposure of cells and tissues to various stressors (Droge, 2002). An imbalance between the production of ROS and reactive intermediate species in biological systems is termed oxidative stress (OS). Radical species such as superoxide $\left(\mathrm{O}_{2}{ }^{-}\right)$, hydroxyl $(\mathrm{OH} \cdot)$, peroxyl $\left(\mathrm{RO}_{2}{ }^{\circ}\right)$, hydroperoxyl $\left(\mathrm{HO}_{2}{ }^{\circ}\right)$, and nonradical species such as hydrogen peroxide $\left(\mathrm{H}_{2} \mathrm{O}_{2}\right)$, singlet oxygen $\left({ }^{1} \mathrm{O}_{2}\right)$, and peroxynitrite $\left(\mathrm{ONOO}^{-}\right)$in excess cause protein oxidation and lipid peroxidation (LPO; Nordberg and Arner, 2001; Dalle-Donne et al., 2002). Protein oxidation is a covalent modification of proteins, which is induced mainly by ROS or by the secondary by-products of OS. Oxidative damage to proteins is considered a key indicator of OS, and protein carbonyl content is a general measure of OS (Davies, 1999). Membrane phospholipids are also subjected to oxidants and LPO involving chain reactions that are initiated by the abstraction of hydrogen atoms of unsaturated fatty acyl chain (Cadenas, 1989; Davies, 1995).

Living organisms, thus, require regulatory systems for protection from ROS. One such system is antioxidant enzymes (AOEs), wherein the primary defense against superoxide anions and hydrogen peroxide is mediated by the action of superoxide dismutase (SOD) and catalase (CAT) (Joanisse and Storey, 1996; Imlay, 2008; Li et al., 2011; Sim and Denlinger, 2011). SOD removes $\mathrm{O}_{2}{ }^{-}$through the process of dismutation to $\mathrm{O}_{2}$ and hydrogen peroxide, whereas CAT breaks down hydrogen peroxide into $\mathrm{H}_{2} \mathrm{O}$ and $\mathrm{O}_{2}$ (Kashiwagi et al., 1997). Hydrogen peroxide accumulation and decreased antioxidant state have been reported in cells under cold stress (O'Kane et al., 1996; An and Choi, 2010). On the contrary, activation of AOEs to overcome the cold-induced OS has been reported by Lalouette et al. (2010). In general, ROS are implicated in the heat stress signal transduction pathway and defense mechanism (Pnueli et al., 2003), and the ontogenic stage has a relevance in increased AOEs in the Oriental fruit fly B. dorsalis subjected to thermal stress (Jia et al., 2011). Increased production of ROS in hypoxic environments, however, remains controversial (Zuo and Clantron, 2005), since the general understanding is that hypoxia leads to increased oxidant production. During hypoxic conditions, oxygen demand exceeds its supply and can promote the disruption of cellular homeostasis and can trigger many cellular responses (Synder and Chandel, 2009). Anoxia/hypoxia is an overwhelming cellular response in most overwintering insects and usually coincides with an increased antioxidant capacity (Sim and Denlinger, 2011). Herbivorous insects often face the challenge from ROS of plant origin (Krishnan and Kodrik, 2006) and from pathogens (Doke et al., 1996), since plant ROS function as a deterrent against insects and pathogens. OS-induced free radicals are considered as pathogenic molecules in viral diseases (Maeda and Akaike, 1991) and lepidopteran larvae infected with virus have shown considerable upregulation of antioxidant mechanism against OS (Lee et al., 2005). Increased level of OS and decreased AOE activities are reported in two of the lepidopteran cell lines infected with virus Autographa californica multiple nuclear polyhedrovirus (Wang et al., 2001), whereas mosquito cells rescues themselves from Dengue virus infection through antioxidant defense (Chen et al., 2011).

The midgut and hemocytes of insects are considered to be highly metabolic, and the midgut is usually susceptible to oxidative injury during food digestion with strong redox potential; the oxidising condition often causes the production of ROS (Krishnan and Kodrik, 2006). High ROS concentration impairs the absorption of ingested nutrients and can cause oxidative damage to the midgut cells (Bi and Felton, 1995). On the other hand, insect hemocytes play an important role in immunity and the respiratory burst 
of hemocytes is often associated with SOD during immune reactions (Minakami and Sumimotoa, 2006; Kavanagh and Reeves, 2007).

The main aim of the work was to evaluate the role of AOEs in maintaining the homeostasis of ROS in silkworm, Bombyx mori, larvae under various stressors. In the present study, we analyzed the altered protein oxidation and LPO levels, activities of AOEs SOD and CAT in the midgut and hemocytes of two instars. We report increased AOEs in both instars to overcome OS when larvae were stressed for a short time, with low temperature, hypoxia, and virus. Our results clearly indicated a possible transitory defense mechanism afforded by AOEs to lessen the OS-induced cellular damage.

\section{MATERIALS AND METHODS}

\section{Chemicals}

Thiobarbituric acid (TBA), horseradish peroxidase, and dinitrophenylhydrazine (DNPH) were purchased from Sigma-Aldrich, (St. Louis, MO). Hydrogen peroxide, Triton X-100, epinephrine, 3,5,3',5'-tetramethylbenzidine (TMB), sodium dodecyl sulfate (SDS), acetic acid, butanol, pyridine, and tetra methoxy propane (TMP) were purchased from Sisco Research Laboratory (Mumbai, India).

\section{Insects and Experimental Design}

The present study was approved by the Institutional Animal Ethics Committee, Bangalore University, Bangalore, India. The second instar larvae were procured from Kunigal seed area, Karnataka, India, and were maintained in laboratory throughout the larval stages and were fed ad libitum on M5 variety mulberry leaves (Vyjayanthi and Subramanyam, 2002a, 2002b). The uniformly grown healthy larvae of IV and V instars were used in all experiments and were maintained at $24-25^{\circ} \mathrm{C}$ with relative humidity of $70-75 \%$. They were made into six groups and each group consisted of hundred. Experimental animals of group I were not subjected to any stress and were considered as control. Group II larvae were subjected to cold treatment at $5^{\circ} \mathrm{C}$ for $24 \mathrm{~h}$, whereas group III was also subjected to cold treatment and maintained at room temperature for an additional period of $12 \mathrm{~h}$ as recovery period. Group IV was subjected to hypoxia for $24 \mathrm{~h}$ and group V larvae were subjected to hypoxia for the same period and were allowed to recover for an additional period of $12 \mathrm{~h}$. Hypoxia was induced by closure of four pairs of posterior spiracles with dental wax and during recovery period all the spiracles were in open state. Group VI larvae were inoculated with $10 \mu \mathrm{l}$ of $1 \times 10^{6} \mathrm{~B}$. mori nuclear polyhedra virus (BmNPV) suspension per gram body weight. Larvae that were injected with $10 \mu \mathrm{l}$ of insect ringer served as sham.

Midgut epithelial cells were isolated by micro dissection and collagenase treatment. Hemolymph was collected in a precooled $2 \mathrm{ml}$ vial containing $5 \mathrm{mg}$ thiourea by gentle incision on caudal horn of the larvae and hemocytes were separated by centrifuging the diluted hemolymph at 3,000 rpm for $10 \mathrm{~min}$ in cold. Cold phosphate buffer of $\mathrm{pH} 7.4$ was used for the tissue homogenate preparation and for the separation of hemocytes or for the isolation of midgut epithelial cells.

\section{Hydrogen Peroxide Generation}

Hydrogen peroxide, a by-product of reactions catalyzed by oxidase, was determined according to Josephy et al. (1982). Two hundred microliters of tissue extract was added to 
incubation mixture that contained $100 \mathrm{nmol}$ of $3,5,3^{\prime}, 5^{\prime}$-TMB and horseradish peroxidase in acetate buffer (0.2 M, pH 5.0). The absorbance was measured at $700 \mathrm{~nm}$ and hydrogen peroxide concentration was expressed as micromole per milligram protein per minute.

\section{LPO Level}

Malanodialdehyde (MDA), a product of LPO was determined as described by Ohkawa et al. (1979). In brief, $200 \mu \mathrm{l}$ of tissue extract was added to $8.1 \%$ SDS, vortexed and incubated for $10 \mathrm{~min}$. Three hundred seventy-five microliters of $20 \%$ acetic acid and $0.6 \%$ TBA were added to the reaction mixture and placed in a boiling water bath for $60 \mathrm{~min}$. The samples were allowed to cool and $1.25 \mathrm{ml}$ butanol:pyridine mixture $(15: 1, \mathrm{v} / \mathrm{v})$ was added and centrifuged at $640 \mathrm{~g}$ for $5 \mathrm{~min}$. Absorbance was measured at $532 \mathrm{~nm}$ using 1,3,3-TMP as standard. MDA concentration was expressed as nanomole per milligram protein.

\section{Protein Carbonyl Level}

Protein carbonyl (PrC) was measured by the method of Uchida and Stadtman (1993). $0.1 \% \mathrm{DNPH}$ in $2 \mathrm{~N} \mathrm{HCl}$ was added to $800 \mu \mathrm{l}$ of tissue extract. Samples were held in the dark for $1 \mathrm{~h}$. The protein was precipitated with $20 \%$ trichloroacetic acid and centrifuged. The pellet was washed thrice with ethanol and ethyl acetate $(1: 1, \mathrm{v} / \mathrm{v})$ and was dissolved in $2 \mathrm{ml}$ of $8 \mathrm{M}$ guanidine hydrochloride, and centrifuged. The supernatant was used to measure the absorbance at $365 \mathrm{~nm}$ and the PrC level was calculated using a molar absorption coefficient of $22,000 \mathrm{M}^{-1} \mathrm{~cm}^{-1}$. The results were expressed as micromolar per milligram protein.

\section{SOD (E.C. 1.15.1.1) Activity}

SOD activity was measured according to Misra and Fridovich (1972) with slight modification. Briefly, $100 \mu \mathrm{l}$ of $5 \%$ tissue extract was added to $880 \mu \mathrm{l}$ of carbonate buffer (0.5 M, pH 10.2). Twenty microliters of epinephrine $(30 \mathrm{mM}$ in $0.05 \%$ acetic acid) was added to the mixture and measured spectrophotometrically (Genway, UK) at $480 \mathrm{~nm}$ for $4 \mathrm{~min}$. SOD activity was measured as the amount of enzyme that inhibits oxidation of epinephrine by $50 \%$, which is equal to 1 unit.

\section{CAT (E.C. 1.11.1.6) Activity}

CAT was determined by method of Aebi (1984). Briefly, $100 \mu$ l enzyme sample with $10 \mu 1$ of absolute alcohol was incubated for $30 \mathrm{~min}$ at $0^{\circ} \mathrm{C}$ followed by addition of $10 \mu \mathrm{l}$ Triton $\mathrm{X}-100$. An aliquot of $50 \mu \mathrm{l}$ was taken in $1.25 \mathrm{ml}$ of $0.066 \mathrm{M} \mathrm{H}_{2} \mathrm{O}_{2}$ in phosphate buffer and decrease in absorbance was measured at $240 \mathrm{~nm}$ for $60 \mathrm{sec}$ in a spectrophotometer. An extinction coefficient of $43.6 \mathrm{M} \mathrm{cm}^{-1}$ was used to determine enzyme activity and was expressed as $1 \mu \mathrm{mol}$ of $\mathrm{H}_{2} \mathrm{O}_{2}$ degraded per minute per milligram protein.

\section{Statistical Analysis}

Data are shown as mean \pm SD of six observations. Changes between the groups were analyzed by MANOVA and further tested by Bonferroni post hoc test using Statistical 
Package for Social Science (SPSS) software (Huberty and Olejnik, 2006) and $P<0.05$ was considered significant. Statistically significant data are presented in the text.

\section{RESULTS}

\section{$\mathrm{H}_{2} \mathrm{O}_{2}$ Generation}

A decrease of temperature from 27 to $5^{\circ} \mathrm{C}$ for $24 \mathrm{~h}$ duration resulted in a significant increase in hydrogen peroxide generation in the midgut tissue and hemocytes in IV and $\mathrm{V}$ instar larvae. In the present experiment, $24 \mathrm{~h}$ was considered the stress period since $\mathrm{H}_{2} \mathrm{O}_{2}$ production was found to be optimal at $18 \mathrm{~h}$ onward. Hypoxia induced by spiracular closure also resulted in a significant increase in $\mathrm{H}_{2} \mathrm{O}_{2}$ in the midgut and hemocytes of both instars. Increased $\mathrm{H}_{2} \mathrm{O}_{2}$ generation induced by low temperature and hypoxia reverted to base value within $12 \mathrm{~h}$ of the recovery period, irrespective of the instars in both of the tissues studied. Increased peroxyl radical generation in midgut cells and hemocytes was observed on viral infection to larvae by hypodermal injection (Fig. 1A and B). V instar
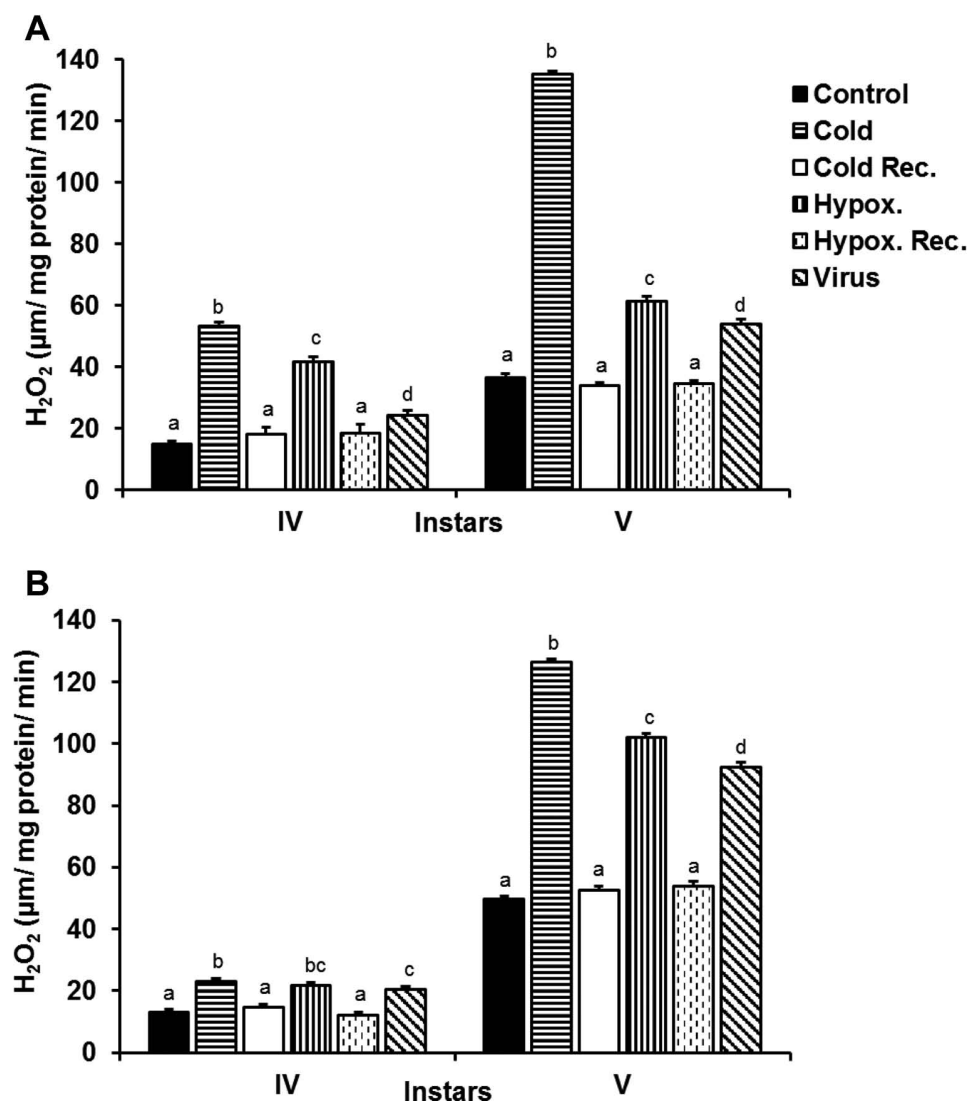

Figure 1. Hydrogen peroxide concentration in silkworm B. mori midgut tissue (A) and hemocytes (B) subjected to cold, cold recovery, hypoxia, hypoxia recovery, and viral infection. Data are means \pm SE $(n=6) . P<0.05$ was considered significant. Values between the stressors are represented in lower cases (a, b, c, d, bc). Those not sharing the same letters are significant. 

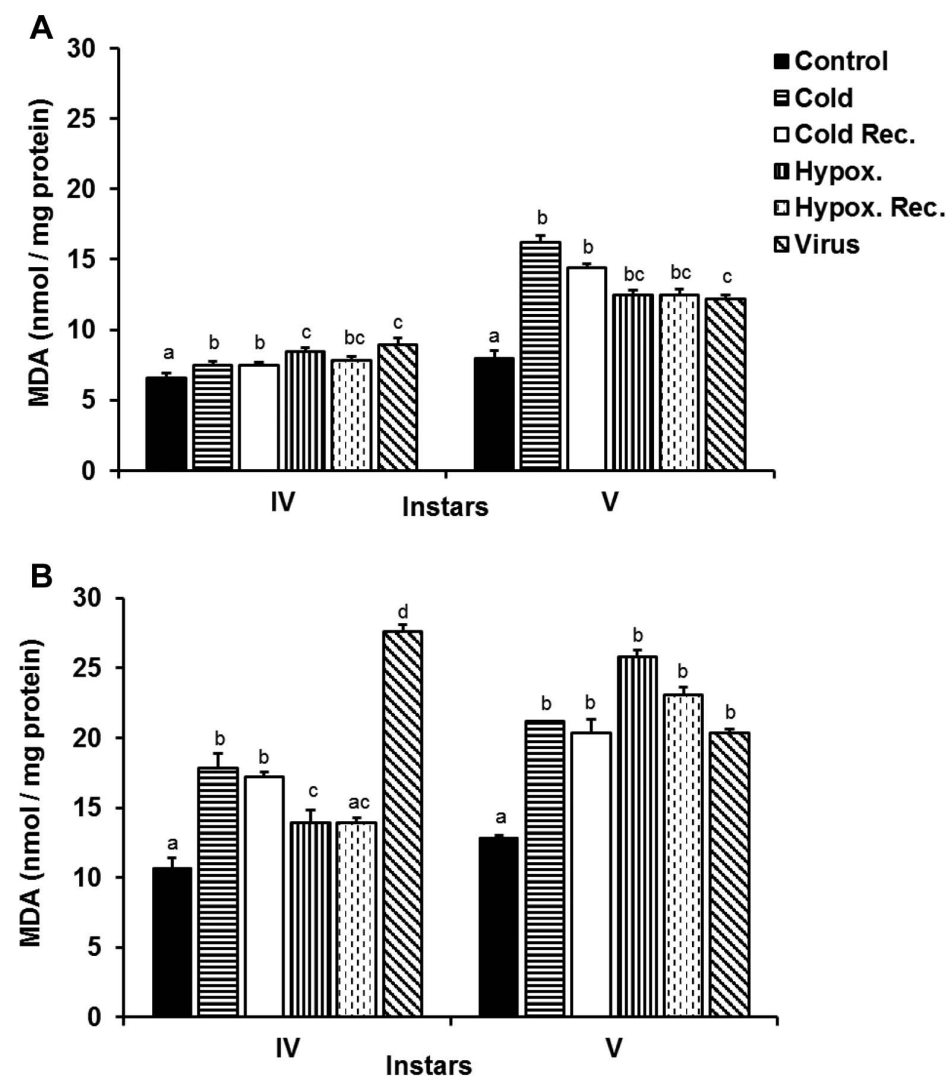

Figure 2. MDA level in silkworm B. mori midgut tissue (A) and hemocytes (B) subjected to cold, cold recovery, hypoxia, hypoxia recovery, and viral infection. Data are means $\pm \mathrm{SE}(n=6) . P<0.05$ was considered significant. Values between the stressors are represented in lower cases (a, b, c, d, ac, bc). Those not sharing the same letters are significant.

larvae showed a significantly higher generation of $\mathrm{H}_{2} \mathrm{O}_{2}$ over IV instar irrespective of the treatment in the tissues studied. Sham-operated larvae were not significantly different from the control group in terms of the $\mathrm{H}_{2} \mathrm{O}_{2}$ generation in both the tissues.

\section{LPO Level}

Free radical induced LPO was observed in midgut tissue and hemocytes of the silkworm larvae. Significant increase in MDA content was observed on cold exposure, hypoxia, viral infection, and also during the recovery period in midgut tissue and hemocytes of both instars (Fig. 2A and B). However, MDA did not show any correlation with the larval stage in the tissues studied.

\section{PrC Level}

PrC level as a marker of protein oxidation increased in the midgut tissue as well as in the hemocytes on exposure to cold, hypoxia, and viruses. The increased PrC content due 

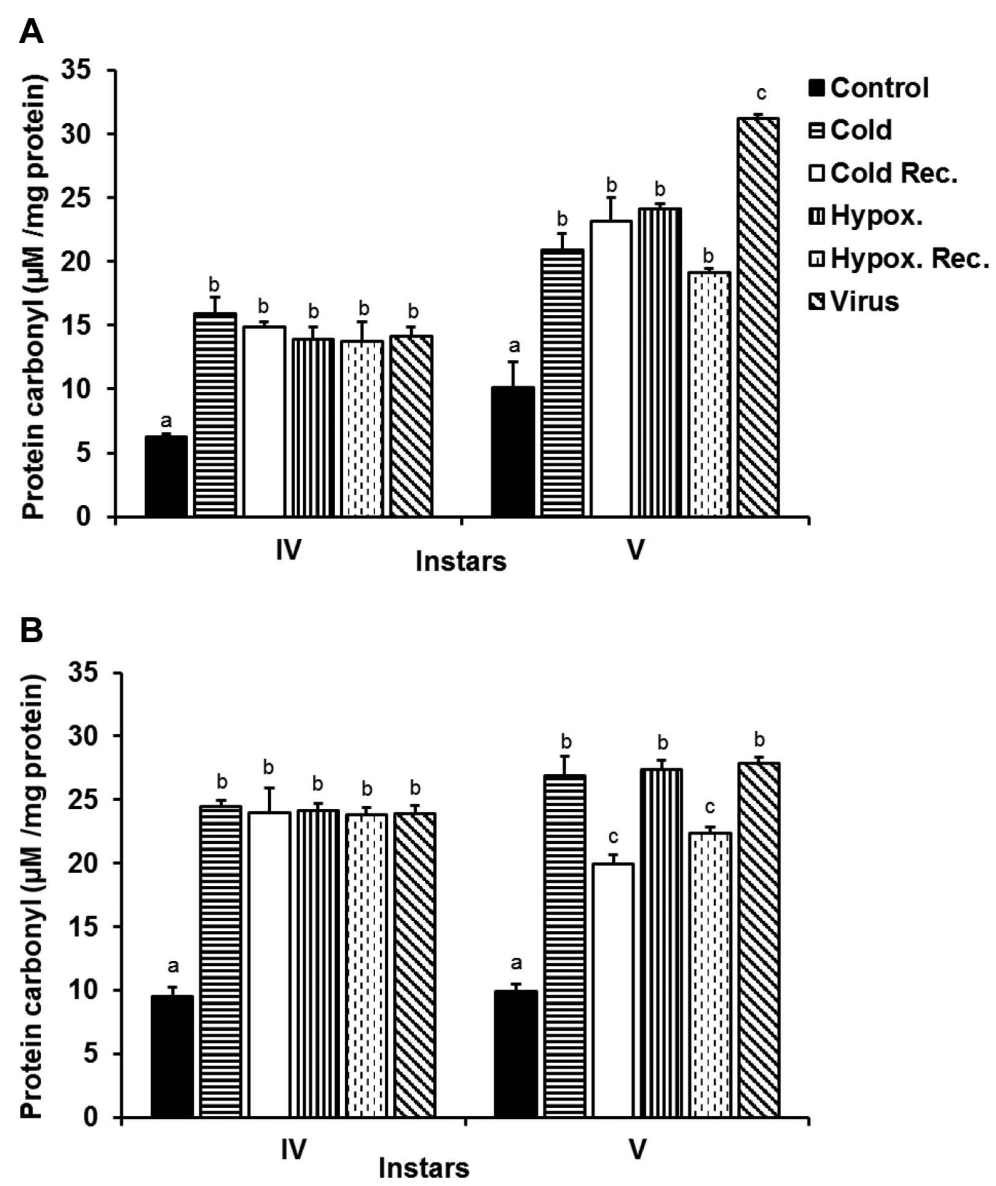

Figure 3. PrC level in silkworm B. mori midgut tissue (A) and hemocytes (B) subjected to cold, cold recovery, hypoxia, hypoxia recovery, and viral infection. Data are means $\pm \mathrm{SE}(n=6) . P<0.05$ was considered significant. Values between the stressors are represented in lower cases $(\mathrm{a}, \mathrm{b}, \mathrm{c})$. Those not sharing the same letters are significant.

to stress remained the same during the recovery period as well in both the instar larvae (Fig. 3A and B).

\section{SOD Activity}

SOD activity in midgut tissue of silkworm larvae under cold stress significantly increased in the IV instar larvae and the increased activity returned to its control value in the recovery period of $12 \mathrm{~h}$. The exposure to hypoxia and viral infection also increased SOD activity significantly in IV instar. Increased SOD activity in the midgut tissue of V instar larvae was also observed upon exposure to all stressors. The extent of increase was relatively higher in the cold when compared to hypoxia and viral infection (Fig. 4A). SOD activity under cold, hypoxia, and viral treatment was also significantly increased in the hemocytes of IV and $\mathrm{V}$ instar larvae (Fig. 4B). However, the enzyme activity in both midgut and hemocytes of $\mathrm{V}$ instar larvae was less than IV instar larvae under various experimental conditions (Fig. 4A and B). 

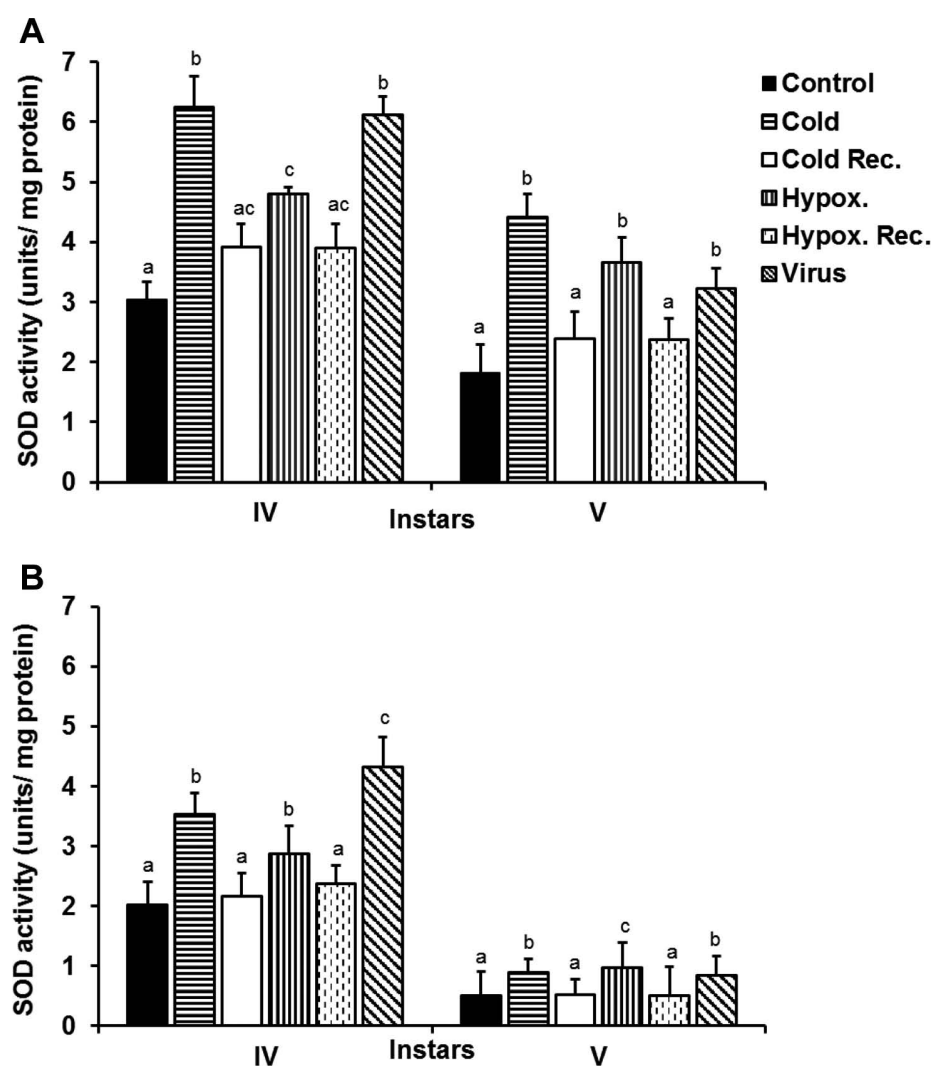

Figure 4. SOD activity in midgut tissue (A) and hemocytes (B) of IV and V instar silkworm B. mori to cold, cold recovery, hypoxia, hypoxia recovery, and viral infection. Data are means $\pm \mathrm{SE}(n=6) . P<0.05$ was considered significant. Values between the stressors are represented in lower cases (a, b, c, ac). Those not sharing the same letters are significant.

\section{CAT Activity}

CAT activity was significantly enhanced in midgut tissues of $B$. mori larvae subjected to all stressors and its activity was found to be higher in IV instar compared to those of $\mathrm{V}$ instar per assay (Fig. 5A). It was also significantly increased in the hemocytes of IV and V instar larvae subjected to various stressors (Fig. 5B). However, activity in the IV instar was significantly higher than that in $\mathrm{V}$ instar larvae (Fig. 5A and $\mathrm{B}$ ).

\section{DISCUSSION}

A cell's early response to different stressful stimuli is to defend against and recover from the insult. Depending on the level and mode of stress, different survival mechanisms are mounted and the reactions are highly conserved in evolution; antioxidant defense is one among the survival mechanisms against oxidative injury (Fulda et al., 2010). In the present study, the lepidopteran larvae were subjected to stressors such as low temperature, hypoxia, and a known pathogen. In the study, midgut epithelium and hemocytes experienced OS, as evidenced by a significant increase in the $\mathrm{H}_{2} \mathrm{O}_{2}$ level during 

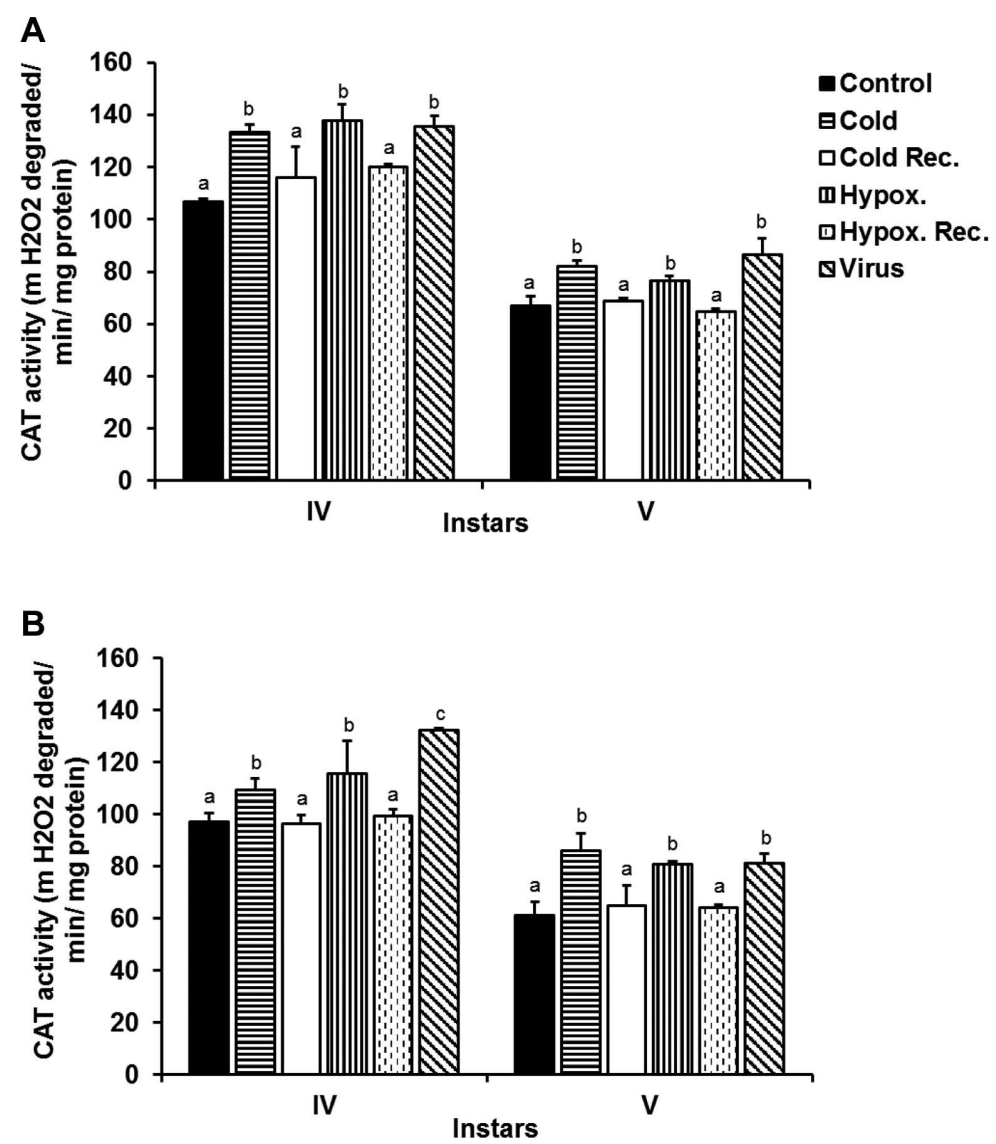

Figure 5. CAT activity in midgut tissue (A) and hemocytes (B) of IV and V instar silkworm B. mori to cold, cold recovery, hypoxia, hypoxia recovery, and viral infection. Data are means $\pm \mathrm{SE}(n=6) . P<0.05$ was considered significant. Values between the stressors are represented in lower cases $(\mathrm{a}, \mathrm{b}, \mathrm{c})$. Those not sharing the same letters are significant.

exposure to stressors. $\mathrm{H}_{2} \mathrm{O}_{2}$ is one of the entities of ROS, with the other being superoxide radical. Hydrogen peroxide is typically produced in peroxisomes as a by-product of reactions catalyzed by oxidases (Kinnula et al., 1992) and, in addition, $\mathrm{H}_{2} \mathrm{O}_{2}$ is released into the cytoplasm via leakage from a range of organelles. Increased $\mathrm{H}_{2} \mathrm{O}_{2}$ generation upon exposure to low temperature, as evidenced in the present study, is similar to the studies on Ostrinia nubilalis subjected to low temperature. Increased levels of $\mathrm{H}_{2} \mathrm{O}_{2}$ and radical properties of melanin accounted for the cold hardiness of this particular insect on exposure to low temperatures (Kojic et al., 2009). Hypoxia can induce elevation in ROS, especially $\mathrm{H}_{2} \mathrm{O}_{2}$ (Giaccia et al., 2004), and increased production of $\mathrm{H}_{2} \mathrm{O}_{2}$ in cardiomyocytes helps in hypoxia-induced ischemia during preconditioning (Zhang et al., 2002). Although elevation in ROS by hypoxia is a known phenomenon, the real mechanism involved has not been explained (Zuo and Clantron, 2005). In our experiments, hypoxia was induced by the closure of the last four pairs of spiracles. We consider the above condition as hypoxia rather than anoxia because the insect's oxygen demand is not met. In our preliminary experiments, we observed an $18 \%$ decrease in oxygen consumption when 
the last four pairs of spiracles were closed. A significant increase in $\mathrm{H}_{2} \mathrm{O}_{2}$ generation in both midgut and hemocytes during hypoxic stress may be reasoned as "reductive stress," involving NADH oxidase or ubiquinone as discussed by Clanton (2005). Cells experience OS following infection with virus (Schweizer and Peterhans, 1999), and such OS mainly occurs by viral challenge at the cell surface rather than viral replication (Kaul et al., 2000). Although ROS is produced in the cytoplasm by oxidases, mitochondria were presumed to be a major source of ROS in virally infected cells (Wang et al., 2001) and oxygen free radicals contribute to pathogenesis in several viral infections (Simula and De Re, 2010; Chen et al., 2011). In the present study, a significant increase in $\mathrm{H}_{2} \mathrm{O}_{2}$ generation in the midgut and hemocytes of $B$. mori larvae infected with NPV was observed. Increase in $\mathrm{H}_{2} \mathrm{O}_{2}$ generation was also reported on viral infection in whole silkworm infected with BmNPV (Li et al., 2011). Hydrogen peroxide can peroxidase the unsaturated lipid of the cell membrane (Fridovich, 1978) and cause the oxidative modification of proteins involving the formation of carbonyl groups in the side chains of certain amino acid residues (Stadtman, 1992; Dalle-Donne et al., 2002). A substantial increase in ROS generation was found in the midgut and hemocytes of both instar larvae and it was concomitant with a significant increase in LPO and protein oxidation, thereby implying that stressors such as hypoxia, cold, and viral infection caused OS leading to damage of the plasma membrane structure and cellular proteins. The correlative relationship among ROS production and oxidative damage in the present study is consistent with the predictions of the OS hypothesis.

Stress induces a rapid production of ROS and their elimination by the antioxidant system is essential for the survival of the animal (McArdle and Jackson, 2000). In dipteran insects, low temperature significantly increased the AOEs (Jia et al., 2011); hypoxia induced by diapause also showed a relationship with free-radical formation and AOEs (Jovanovica-Galovic, 2007) and an increase in AOEs was also found in silkworm on pathogenic infection (Wang et al., 2001; Krishnan et al., 2002). Viral infection activates the translation of host genes causing responses involving unfolded proteins (Patramool et al., 2011), whereas alteration in SOD 1 following Rift Valley fever virus (RVFV) infection and simultaneous activation of p38 mitogen activated protein kinase (p38 MAPK) were implicated for improving survival of infected cells (Narayanan et al., 2011). Mosquito cells use antioxidant mechanism to survive Dengue virus infection (Chen et al., 2011) and upregulated gluthion S-transferase (GST) found to be responsible for the survival of mosquito cells infection with Dengue virus (DENV) (Lin et al., 2007). Exposure to low temperature, hypoxia, or inoculation with BmNPV resulted in a significant increase in AOEs in the fourth and fifth instar larvae. Increased SOD and CAT activities in the fifth instar were relatively less when compared to the fourth instar. A concomitant increase in $\mathrm{H}_{2} \mathrm{O}_{2}$ in both tissues was also evident, especially in the fifth instar, due to increased OS associated with the ontogenic stage of silkworms. Variations in antioxidant system in ontogenesis have been reported in the beetle Tenebriomolitor (Gulevsky et al., 2006a, 2006b). In contrast to the present findings, studies on lepidopteran larvae infected with NPV have indicated a reduction of AOEs and reasoned it for increased LPO (Li et al., 2011). The current study was restricted to the immediate response of larval oxidative and antioxidant system subjected to the stress exposure and on recovery. An increase in the ROS and oxidative products were observed along with a simultaneous increase in AOEs during the stress period and reversal during recovery period. The present study clearly indicates enhanced AOEs, which may function as an immediate defense mechanism to overcome the oxidative insult induced by single exposure to cold, hypoxia, and virus. 


\section{ACKNOWLEDGMENTS}

Ann Sandhya Micheal acknowledges Council for Scientific and Industrial Research (CSIR), New Delhi, India for research fellowship.

\section{LITERATURE CITED}

Aebi H. 1984. Catalase in vitro. Methods Enzymol 105:121-126.

An MI, Choi CY. 2010. Activity of antioxidant enzymes and physiological response in ark shell, Scapharca broughtonii, exposed to thermal and osmotic stress: effects on haemolymph and biochemical parameters. Comp Biochem Physiol B Biochem Mol Biol 155:34-42.

Bi JL, Felton GW. 1995. Foliar oxidative stress and insect herbivory: primary compounds, secondary metabolite and reactive oxygen species as components of induced resistance. J Chem Ecol 21:1511-1530.

Cadenas E. 1989. Biochemistry of oxygen toxicity. Annu Rev Biochem 58:79-110.

Chen TH, Tang P, Yang CF, Kao LH, Lo YP, Chuang CK, Shin YT, Chen WJ. 2011. Antioxidant defense is one of the mechanism by which mosquito cells survive Dengu 2 viral infection. Virology 410:410-417.

Clanton T. 2005. Yet another oxygen paradox. J Appl Physiol 99:1245-1246.

Dalle-Donne I, Rossi R, Giustarini D, Milazani A, Colombo R. 2002. Protein carbonyl groups as biomarkers of oxidative stress. Clin Chim Acta 329:23-138.

Davies KJA. 1995. Oxidative stress: the paradox of aerobic life. Biochem Soc Symp 61:1-13.

Davies KJA. 1999. The broad spectrum of responses to oxidants in proliferating cells: a new paradigm for oxidative stress. IUBMB Life 48:41-47.

Doke N, Miura Y, Sanchez LM, Park HJ, Noritake T, Yoshioka H, Kawakita K. 1996. The oxidative burst protects plants against pathogen attack: mechanism and role as an emergency signal for plant bio defense. Gene 179:45-51.

Droge W. 2002. Free radicals in the physiological control of cell function. Physiol Rev 82:47-95.

Fridovich I. 1978. The biology of oxygen radicals. Science 201:875-879.

Fulda S, Gorman AM, Hori O, Samali A. 2010. Cellular stress responses: cell survival and cell death. Int J Cell Biol 1-23, 214074. doi: 10.1155/2010/214074

Giaccia AJ, Simon MC, Johnson R. 2004. The biology of hypoxia: the role of oxygen sensing in development, normal function and disease. Genes Dev 18:2183-2194.

Gulevsky AK, Relina LI, Grishchenkova YA. 2006a. Variation of the antioxidant system during development of the cold-tolerant beetle, Tenebriomolitor. Cryo Letters 27:283-290.

Gulevsky AK, Grishchenkova YA, Relina LI. 2006b. Antioxidant system in the darkling beetle (Tenebriomolitor) in ontogenesis. Ukr Biokhim Zh 78:86-90.

Huberty CJ, Olejnik S. 2006. Applied MANOVA and discriminate analysis. New Jersey: John Wiley and Sons.

Imlay JA. 2008. Cellular defenses against superoxide and hydrogen peroxide. Annu Rev Biochem 77:755-776.

Jia F-X, Dou W, Hu F, Wang JJ. 2011. Effect of thermal stress on lipid peroxidation and antioxidant enzyme activities of Oriental fruit fly, Bactrocera dorsalis. Fla Entomol 94:956-963.

Joanisse RD, Storey KB. 1996. Oxidative stress and antioxidants in overwintering larvae of cold-hardy goldenrod gall insects. J Exp Biol 199:1483-1491.

Josephy PD, Elings T, Mason RP. 1982. The horseradish peroxidase catalysed oxidation of 3,5,3',5'tetramethylbenzidine. J Biol Chem 257:3669-3675. 
Jovanovica-Galovic A, Blagojevic DP, Grubor-Lajsic G, Worland MR, Spasic MB. 2007. Antioxidant defense in mitochondria during diapause and post diapause development of European corn borer (Ostrina nubulalis, Hubu). Arch Insect Biochem Physiol 64:111-119.

Kashiwagi A, Kashiwagi K, Takase M, Hanada H, Nakamura M. 1997. Comparison of catalase in diploids and haploid Ranarugosa using heat and chemical inactivation techniques. Comp Biochem Physiol B Biochem Mol Biol 118:499-503.

Kaul P, Biagiole MC, Singh I, Turner RB. 2000. Rhinovirus-induced oxidative stress and interlukin 8 elaboration involves p47-Phox but is independent of attachment to intracellular adhension molecule-1 and viral replication. J Infect Dis 181:1885-1890.

Kavanagh K, Reeves EP. 2007. Insect and mammalian innate immune response are much alike. Microbe 2:596-599.

Kinnula VL, Whorton AR, Chang LY, Crapo JD. 1992. Reaction of $\mathrm{H}_{2} \mathrm{O}_{2}$ generation in cultured endothelial cells. Am J Respir Cell Mol Biol 6:175-182.

Kojic D, Spasojevic I, Mojovic M, Blagojevic D, Worlan MR, Grubor-Lajsic G, Spasic MB. 2009. Potential role of hydrogen peroxide and melanin in the cold hardiness of Ostrinia nubilalis (Lepidoptera: Pyralidae). Eur J Entomol 106:451-454.

Krishnan N, Kodrik, D. 2006. Antioxidant enzymes in Spodoptera littoralis (Biosduval): are they enhanced to protect gut tissue during oxidative stress? J Insect Physiol 52:11-20.

Krishnan N, Chattopadhyay Y, Kundu JK, Chaudhuri A. 2002. Superoxide dismutase activity in haemocytes and haemolymph of Bombyx mori following bacterial infection. Curr Sci 83: $3-10$.

Lalouette L, Williams CM, Hervant F, Sinclair BJ, Renault D. 2010. Metabolic rate and oxidative stress in insects exposed to low temperature thermal fluctuations. Comp Biochem Physiol A Biochem Mol Biol 158:229-234.

Lee KS, Kim SR, Park NS, Kim I, Kang PD, Sohn BH, Choi KH, Kang SW, Je YH, Lee SM, Sohn HD, Jin BR. 2005. Characterization of a silkworm thioredoxin peroxidase that is induced by external temperature stimulus and viral infection. Insect Biochem Mol Biol 35:73-84.

Li B, Xie Y, Cheng Z, Cheng J, Hu R, Cui Y, Gong X, Shen W, Hong F. 2011. Effects of added $\mathrm{CeCl}_{3}$ on resistance of fifth-instar larvae of silkworm to Bombyx mori nucleopolyhedrovirus infection. Biol Trace Elem Res 146:318-324.

Lin CC, Yang CF, Tu CH, Huang CG, Shih YT, Chuang CK, Chen WJ. 2007. A novel tetraspanin C 189 up regulated in C6/36 mosquito cells following Dengu 2 virus infection. Virus Res 124:176-183.

Maeda H, Akaike T. 1991. Oxygen free radicals as pathogenic molecules in viral diseases. Proc Soc Exp Biol Med 198:721-727.

McArdle A, Jackson MJ. 2000. Exercise, oxidative stress and ageing. J Anat 197:539-541.

Minakami R, Sumimotoa H. 2006. Phagocytosis - coupled activation of the superoxide producing phagocyte oxidase, a member of the NADPH oxidase family. Int J Hematol 84:193-198.

Misra HP, Fridovich I. 1972. The role of superoxide anion in the autoxidation of epinephrine and a simple assay of superoxide dismutase. J Biol Chem 247:3170-3175.

Narayanan A, Popova T, Turell M, Kidd J, Chertow J, Popov SG, Bailey C, Kashanchi F, Kehn-Hall K. 2011. Alteration in superoxide dismutase 1 causes oxidative stress and p38 MAPK activation following RVFV infection. PLoS One 6(5):e20354. doi: 10.1371/journal.pone.0020354.

Nordberg J, Arnér ESJ. 2001. Reactive oxygen species, antioxidants, and the mammalian thioredoxin system1. Free Radic Biol Med 31:1287-1312.

O'kane D, Gill V, Boyd P, Burdon R. 1996. Chilling, oxidative stress and antioxidant responses in Arabidopsis thaliana callus. Planta 198:371-377.

Ohkawa H, Ohishi M, Yagi K. 1979. Assay for lipid peroxidation in animal tissues by thiobarbituric acid reaction. Anal Biochem 95:351-358. 
Patramool S, Surasombatpattana P, Luplertlop N, Se've'no M, Choumet V, Thomas F, Misse D. 2011. Proteomic analysis of an Aedes albopctus cell line infected with Dengu serotypes 1 and 3 viruses. Parasit Vectors 4:138-147.

Pnueli L, Liang H, Rozenberg M, Mittler R. 2003. Growth suppression, altered stomatal responses, and augmented induction of heat shock proteins in cytosolic ascorbate peroxidase (Apx1)deficient Arabidopsis plants. Plant J 34:185-201.

Schweizer M, Peterhans E.1999. Oxidative stress in cells infected with bovine viral diarrhea virus: a crucial step in the induction of apoptosis. J Gene Virol 80:1147-1155.

Sim C, Denlinger DL. 2011. Catalase and superoxide dismutase-2 enhance survival and protect ovaries during overwintering diapause in the mosquito Culex pipiens. J Insect Physiol 57:628634.

Simula MP, De Re V. 2010. Hepatitis C virus- induced oxidative stress in mitochondrial dysfunction: a focus on recent advances in proteomics. Proteomics Clin Appl 4:782-793.

Stadtman ER. 1992. Protein oxidation and ageing. Science 257:1220-1224.

Synder CM, Chandel NS. 2009. Mitochondrial regulation of cell survival and death during low oxygen conditions. Antioxid Redox Signal 11:2673-2683.

Uchida K, Stadtman ER. 1993. Covalent attachment of 4 - hydrosynoneal to glyceradehyde 3phosphate dehydrogenase. J Biol Chem 268:6388-6393.

Vyjayanthi N, Subramanyam M. 2002a. Effect of fenvalerate - 20EC on sericigenous insect: I. Food utilization in the late age larva of silkworm B. mori. Ecotoxicol Environ Safety 53:206.

Vyjayanthi N, Subramanyam M. 2002b. Effect of fenvalerate - 20EC on sericigenous insect: II. Digestive enzymes in the nutritive physiology of silkworm B. mori. Ecotoxicol Environ Safety $53: 212$.

Wang Y, Oberley LW, Murhammer DW. 2001. Evidence of oxidative stress following the viral infection of two lepidopteran insect cell lines. Free Radic Biol Med 31:1448-1445.

Zhang HY, McPherson BC, Liu H, Baman TS, Rock P, Yao Z. 2002. Hydrogen peroxide opens mitochondrial ATP channels and inhibit gamma receptors via protein kinase $\mathrm{C}$ in cardiomycetes. Am J Physiol 282:H1395-H1403.

Zuo L, Clantron TL. 2005. Reactive oxygen species formation in the transition to hypoxia in skeletal muscles. Am J Physiol 289:C207-C216. 